Aquat. Living Resour., 1994, 7, 47-52

\title{
Light and electron immunohistochemical assays on paramyxean parasites
}

\author{
Timothy J. Anderson (1), Thomas F. McCaul (2), \\ Viviane Boulo ${ }^{(3)}$, Jose A. F. Robledo ${ }^{(4)}$ and Robert J. G. Lester ${ }^{(1)}$ \\ (1) Department of Parasitology, University of Queensland, Australia, 4072. \\ (2) Centre for Microscopy and Microanalysis, University of Queensland, Brisbane, 4072 Australia. \\ (3) IFREMER-URPIGM, BP 133, 17390 La Tremblade, France. \\ (4) Instituto de Investigaciones Marinas - CSIC, Eduardo Cabello 6, 36208 Vigo Spain.
}

Received March 5, 1993; accepted June 1, 1993.

Anderson T. J., T. F. McCaul, V. Boulo, J. A. F. Robledo, R. J. G. Lester. Aquat. Living Resour., 1994, 7, 47-52.

Abstract

An indirect fluorescent antibody test (IFAT) incorporating a polyclonal antibody to Marteilia sydneyi recognized sporulating stages of $M$. sydneyi from Saccostrea commercialis but not those of Marteilia refringens, M. maurini, Marteilia sp. and Marteilioides branchialis from Ostrea edulis, Mytilus galloprovincialis, Mytilus edulis and Saccostrea commercialis respectively. This indicates that the antibody had a high specificity and that the other parasites were immunologically distinct from $M$. sydneyi. Immunoelectron microscopy was used to investigate background labelling and the specificity of the antibody to antigenic sites. It showed that though most immunoglobulins were specific to parasite epitopes, some reacted to host tissue. IFAT's based on three monoclonal antibodies raised against Marteilia sp. did not recognise spores or other stages of $M$. sydneyi. An immunogold-silver staining technique using the polyclonal antibody to $M$. sydneyi failed to identify the presumed presporulation stage of $M$. sydneyi in the connective tissue of a recently infected host. This suggests the antigens were stage-specific. Thus a DNA probe rather than immunohistochemical tests may be more useful in investigating the life cycle of this parasite.

Keywords: Disease diagnosis, life cycle, immunolabelling, antibody, Marteilia, Marteilioides, Paramyxea, oyster, Saccostrea commercialis.

Tests immuno-histochimiques sur les paramyxines parasites en microscopie optique et en microscopie électronique

Résumé

Dans un test en immunofluorescence indirecte, des anticorps polyclonaux spécifiques de Marteilia sydneyi ont réagi positivement contre les formes sporulées de ce parasite associé à l'huître Saccostrea commercialis. Par contre, aucune réaction n'a été observée avec les formes sporulées de Marteilia refringens, M. maurini, Marteilia sp. et Marteilioides branchialis qui sont respectivement associées à Ostrea edulis, Mytilus galloprovincialis, Mytilus edulis et Saccostrea commercialis. Ces résultats ont montré que les anticorps polyclonaux sont hautement spécifiques et que les autres parasites sont immunologiquement différents de $M$. sydneyi. La réactivité des anticorps a été étudiée en microscopie électronique, ce qui a révélé que la majorité des immunoglobulines sont spécifiques d'épitopes parasitaires, certaines réagissant avec les tissus de l'hôte. Par ailleurs, trois anticorps monoclonaux spécifiques de Marteilia sp., parasite de Mytilus edulis se sont révélés négatifs en immunofluorescence indirecte vis-à-vis des spores et des autres stades de $M$. sydneyi. Selon la technique d'immunogold, les anticorps polyclonaux spécifiques de $M$. sydneyi n'ont pas permis d'identifier le stade présporal présumé de ce parasite dans le tissu conjonctif d'un hôte récemment infecté. Ceci suggère que ces anticorps sont spécifiques de certains stades. Ainsi, un test utilisant une sonde ADN pourrait être mieux adapté que des tests immunologiques pour étudier le cycle de développement de ce parasite.

Mots-clés : Diagnostic, immuno-marquage, anticorps, Marteilia, Marteilioides, Paramyxine, huître, Saccostrea commercialis. 


\section{INTRODUCTION}

Two genera of the phylum Paramyxea contain important shellfish disease agents - Marteilia and Marteilioides. Marteilia sydneyi (Perkins and Wolf, 1976) is a parasite of the Sydney Rock Oyster, Saccostrea commercialis causing QX disease. The disease occurs in Australian oyster growing estuaries from Tin Can Bay, Queensland to the Macleay River, New South Wales (Witney et al., 1988). Outbreaks occur in summer to early autumn, often follow heavy rains (Lester, 1986) and cause economic losses, sometimes in excess of $90 \%$ of a lease (Anderson and Lester, 1992; Lester, 1986). The pathogen sporulates within the digestive gland of its host causing the organ to atrophy and most of the host tissue to be replaced by parasite tissue.

Marteilioides branchialis (Anderson and Lester, 1992) infects the gills of Saccostrea commercialis and was first found in association with QX disease in the Clarence River, New South Wales. Although pathogenesis of the parasite is not fully known, clinical signs of the disease are multi-focal lesions in the gills.

Other paramyxeans infecting commercial molluscs are in the genus Marteilia. Marteilia refringens (Comps, 1970; Grizel et al., 1974) is the cause of Aber disease in the European flat oyster (Ostrea edulis), and possibly occurs in the Pacific oyster (Crassostrea gigas) and blue mussels (Mytilus edulis) and (M. galloprovincialis) (Robledo et al., in press). Marteilia maurini (Comps et al., 1982) occurs in both Mytilus edulis and M. galloprovincialis. Though Marteilia refringens causes economic losses of oysters, $M$. maurini has not caused any significant mortality and paramyxeans in mussels appear to be non-pathogenic (Robledo et al., in press). An indirect fluorescent antibody test (IFAT) incorporating monoclonal antibodies (MAbs) against Marteilia sp. (presumably $M$. refringens) has been used by Robledo et al. (in press) to distinguish these two species of Marteilia. In this paper, three MAbs against Marteilia sp. infecting $M$. edulis from Brittany, France that were produced by Robledo et al. (in press) are tested for cross-reactivity with $M$. sydneyi to determine if they can be used in routine diagnosis of $M$. sydneyi.

An understanding of the life cycle of $M$. sydneyi is paramount in developing effective ways to combat QX disease. However, no paramyxean life cycle is known. In $M$. sydneyi it may be indirect as attempts to transfer the parasite directly from oyster to oyster have been unsuccessful (Lester, 1986). Roubal et al. (1989) implicated filter-feeding or detritivorous invertebrates as intermediate hosts in the life cycle because living infected oysters shed sporonts. The infective presporulation stage entering the oyster is unknown but is likely to occur in the connective tissue of the digestive gland which is the site of an inflammatory response early in the infection (Lester, 1986). Localisation and identification of the early infective stage would help in the elucidation of the life cycle. An immunoassay could do this and also identify the parasite in an alternate host or elsewhere in the environment. An IFAT incorporating a polyclonal antibody (PAb) was developed by Roubal et al. (1989) to identify sporulating stages of QX. Since a polyclonal antibody has a greater potential for detecting stage-specific antigens than a MAb (Burreson, 1988), the IFAT for QX (QX IFAT) is used in this study in an attempt to identify other stages in the life cycle of $M$. sydneyi.

\section{MATERIALS AND METHODS}

\section{Specimens}

\section{Smears}

Smears of tissue from five molluscs each infected with a different paramyxean were made on glass slides in 1991/1992. Unfixed smears of Marteilia sydneyi from Moreton Bay, Qld, Australia and Marteilioides branchialis from the Clarence R., N. S. W., Australia, both from Saccostrea commercialis, were processed immediately or stored at $-20^{\circ} \mathrm{C}$. Unfixed smears of Marteilia refringens from Ostrea edulis from Brittany, France, Marteilia maurini from Mytilus galloprovincialis from Galicia, Spain, Marteilia sp. from Mytilus edulis from Brittany, France and their hosts (controls) spent up to 10 days in the mail at ambient temperature prior to processing.

\section{Tissues}

For light microscopy, infected oyster tissues were fixed in Davidson's Fluid (Humason, 1979) for 6 to $18 \mathrm{~h}$ at $20^{\circ} \mathrm{C}$, dehydrated in alcohol and embedded in paraffin. Histological sections $(5 \mu \mathrm{m})$ were placed on glass slides, baked for 6 to $18 \mathrm{~h}$ at $50^{\circ} \mathrm{C}$ to ensure good adhesion, deparaffinised in xylene, rehydrated through a graded series of methanol, and rinsed in water. For immunoelectron microscopy, pieces of QX-infected digestive gland were fixed in $1.25 \%$ glutaraldehyde with $0.2 \%$ picric acid in $0.066 \mathrm{M}$ cacodylate buffer, $\mathrm{pH} 7.2$ at $4{ }^{\circ} \mathrm{C}$ for 6 to $18 \mathrm{~h}$. The tissues were dehydrated in methanol and embedded in L. R. White. Ultrathin sections were mounted on nickel grids prior to immunolabelling.

\section{Primary antisera}

The polyclonal anti-QX antibody was developed by Roubal et al. (1989). Basically, sporonts of QX from the digestive gland of Saccostrea commercialis were purified using discontinuous sucrose and Percoll gradients, then used to raise polyclonal antibodies in rabbits. Three monoclonal antibodies directed against sporulating stages of Marteilia sp. purified from Mytilus edulis from Brittany, France were used. Their production is described by Robledo et al. (in press). 


\section{Adsorption of oyster tissue antibodies}

QX antiserum, diluted 1:10 in phosphate-buffered saline (PBS), was added to aliquots of homogenized QX-free oyster tissue that had been serially diluted in PBS. The aliquots were kept at $4{ }^{\circ} \mathrm{C}$ for $2 \mathrm{~h}$, then centrifuged to pellet the antigen-antibody complexes. The supernatant containing unadsorbed parasite antibodies was removed and used as primary antisera.

\section{Immunohistochemical assays}

Smears, deparaffinised histological sections or ultrathin sections were rinsed twice in Tris-buffered saline (TBS: $0.15 \mathrm{M} \mathrm{NaCl}$ in $0.02 \mathrm{M}$ Tris, $\mathrm{pH} \mathrm{7.2)}$ containing $0.1 \%$ bovine serum albumin (BSA), coated with rabbit anti-QX primary antiserum (dilution 1:100 [see Roubal et al., 1989] in TBS/BSA pH 8.1) or an IgG anti-Marteilia sp. monoclonal antibody (cell line $12 \mathrm{~B} 9,1 \mathrm{~F} 10$, or $4 \mathrm{~B} 8$ ) for $1 \mathrm{~h}$ at $20^{\circ} \mathrm{C}$ and rinsed in TBS/BSA pH 7.2 prior to incubation with a secondary antibody.

\section{Indirect immunofluorescence}

Smears or tissues on glass slides that had been incubated with the polyclonal antibody were overlaid with a FITC conjugated goat anti-rabbit IgG (whole molecule, Sigma), diluted to $1: 40$ in TBS/BSA pH 8.1 , for $30 \mathrm{~min}$ at $20^{\circ} \mathrm{C}$. An FITC conjugated goat anti-mouse IgG (whole molecule, Sigma) diluted to 1:60 was used for indirect labelling when monoclonal antibodies were used as primary antibodies. After labelling, the preparations were washed twice in TBS/BSA $\mathrm{pH} 7.2$, then water, and examined and photographed using an Olympus fluorescent microscope.

\section{Immunogold-silver staining technique}

The sections on glass slides were overlaid with a $10 \mathrm{~nm}$ gold-labelled goat anti-rabbit IgG secondary antibody (diluted 1:20 in TBS/BSA $\mathrm{pH} 8.1$ ) for $30 \mathrm{~min}$ at $20^{\circ} \mathrm{C}$. The sections were washed twice in TBS/BSA pH 7.2, then water. The colloidal-gold was silver stained using an Amersham silver enhancement kit to enhance the visibility of the antigen-antibody complexes. Specimens were photographed under bright light and also viewed under a polarized light Olympus epi-illumination microscope.

\section{Immunoelectron microscopy}

Sections on nickel grids were immersed in a $10 \mathrm{~nm}$ gold-labelled goat anti-rabbit IgG secondary antibody (diluted 1:20 in TBS/BSA pH 8.1) for $30 \mathrm{~min}$ at $20^{\circ} \mathrm{C}$. The sections were washed twice in TBS/BSA pH 7.2, then water, and stained with uranyl acetate/lead citrate before viewing in the Hitachi H800 transmission electron microscope. Controls in all assays consisted of omitting either the primary or secondary antibody and using uninfected oyster smears, and adjacent sections of infected tissue.

\section{RESULTS}

The polyclonal antibody against Marteilia sydneyi, used in an IFAT on deparaffinized histological sections of an oyster digestive gland infected with sporulating stages of $M$. sydneyi, yielded strong positive reactions to the parasite and some low background labelling of host (fig. 1). Immunoelectron microscopy on ultrathin sections of a digestive gland infected with $M$. sydneyi was used to investigate this background labelling, and the specificity of the PAb to antigenic sites. The refringent granules were more heavily labelled than other structures (fig. 2). There was some low background labelling of oyster cell membranes. After purification of the antibody by adsorbing those antibodies which recognise oyster cells, the intensity of gold-labelling to parasite and host tissue was proportional to the dilution of oyster antigen and there were no dilutions at which significant labelling occurred with parasite but not with oyster cell, i.e. adsorption appeared to reduce the reactivity of the antibody to both parasite and host tissue.

Testing of the QX IFAT on smears of $M$. sydneyi, $M$. refringens, $M$. maurini, Marteilia sp. and $M$. branchialis resulted in positive reactions to sporonts of $M$. sydneyi and negative reactions for the others.

The immunogold-silver staining technique (IGSS) designed for paraffin sections (Springall et al., 1984), was performed as a comparison to the IFAT to determine which method confers the greatest sensitivity in diagnosing sporulating stages of $M$. sydneyi. With similar histological sections used for the IFAT, positive reactions occurred with the IGSS technique and there appeared to be less background staining which may have been due to the different secondary antibodies used (fig. 3). Polarized light epiillumination microscopy detected these immunogoldsilver stained parasites with higher sensitivity.

The IGSS technique was performed on deparaffinized histological sections of a digestive gland suspected to be infected with infective stages of QX (acquired on January 25th, 1982; see Lester, 1986) because the connective tissue was inflamed and spores were found in other oysters in the sample two weeks later. No parasites were detected.

Three of the MAbs produced against Marteilia sp. were tested for cross-reactivity with smears of $M$. sydneyi using the IFAT. No cross-reactions were detected.

In all tests, control sections and smears of uninfected and infected tissues were negative. Control uninfected tissues used in the tests incorporating the polyclonal antibody showed labelling of similar intensity to the bacground labelling observed in infected tissues.

\section{DISCUSSION}

Colloidal gold-labelling of sites within the parasite, using immunoelectron microscopy (IEM) and the 


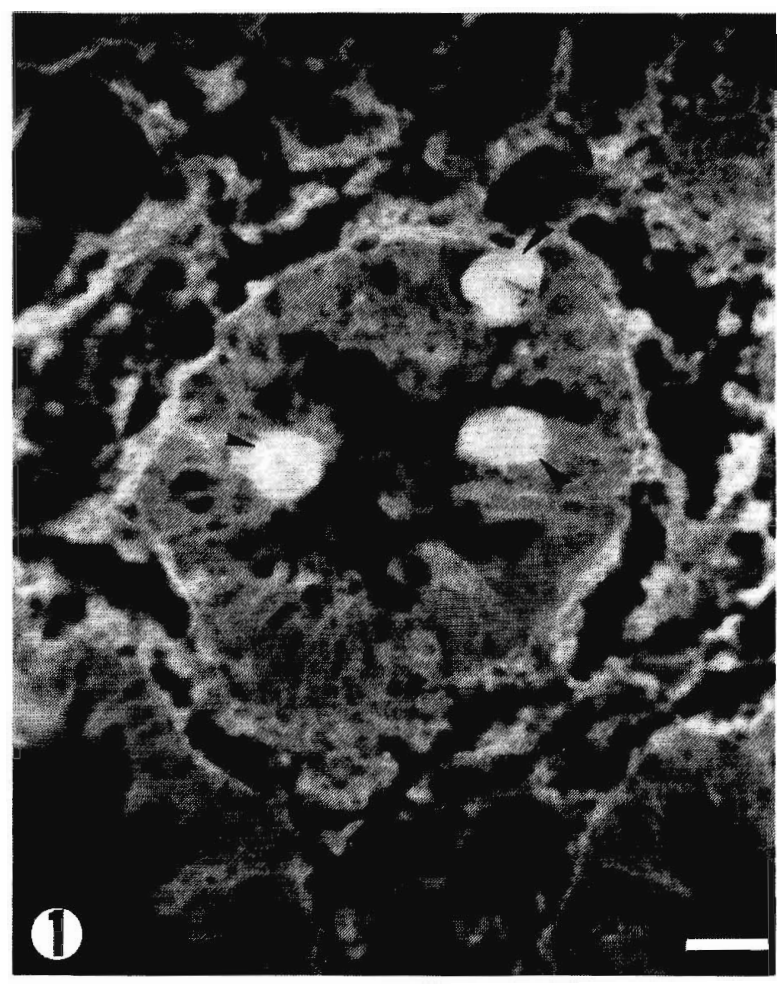

Figures 1-3. - Positive reactions to sporulating stages of Marteilia sydneyi using immunoassays incorporating a polyclonal antibody against $M$. sydneyi.

1. An indirect fluorescent antibody test applied to a histological section of an infected oyster digestive gland. Arrows indicate three mature stages of the parasite recognised by the polyclonal antibody. Note low background labelling of host tissue. Bar $=25 \mu \mathrm{m}$.

2. Immunoelectron microscopy on an ultrathin section of an infected oyster digestive gland showing the specificity of the antibody within a sporont. The refringent granules ( $R$ ) are heavily labelled. Bar $=1 \mu \mathrm{m}$. 3. The immunogold-silver staining technique applied to a histological section of infected tissue. Arrow indicates a gold-silver stained mature stage with 8 sporonts. Bar $=25 \mu \mathrm{m}$.

same polyclonal antibody, were similar to those reported by Roubal et al. (1989) except that they used purified parasites for IEM. We attempted to reduce the background labelling in the sections of infected tissue to improve the specificity of the antibody for QX diagnosis and maximise our chances of detecting the unknown infective stage of $M$. sydneyi since
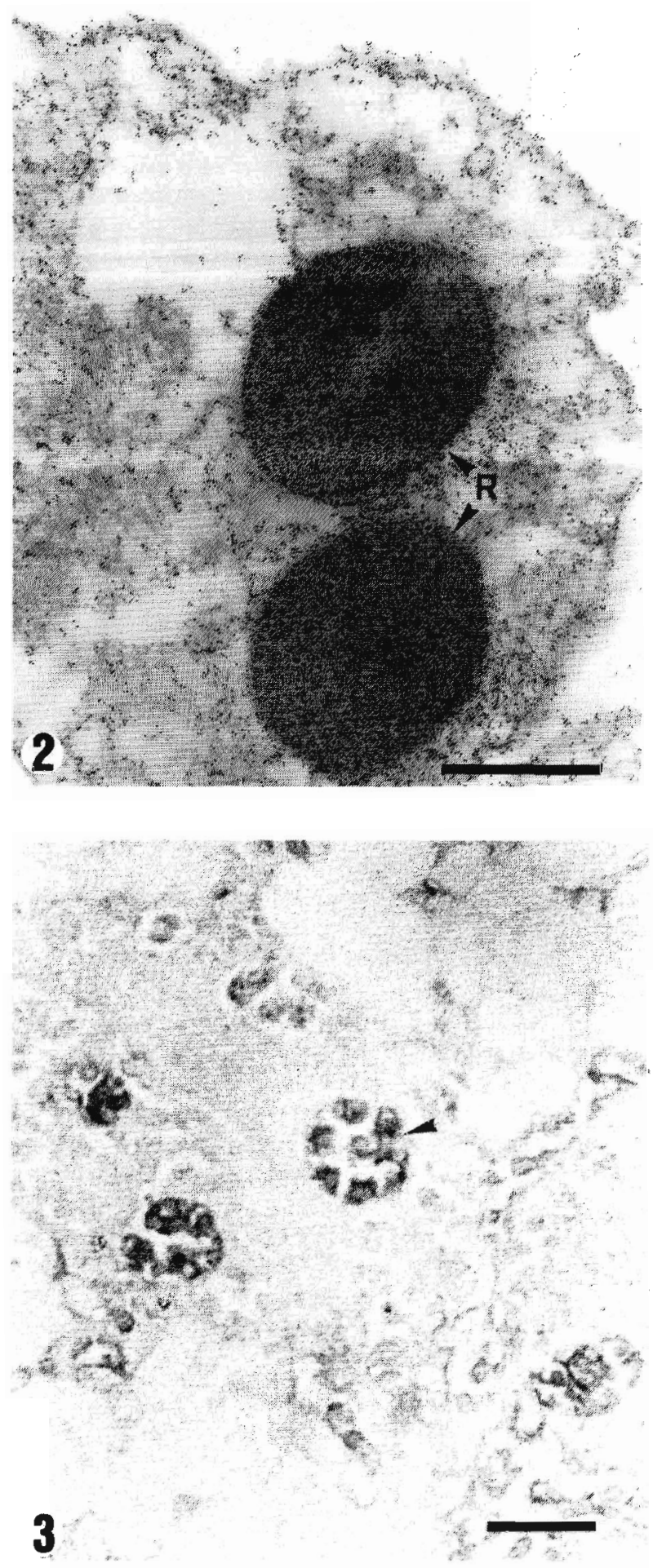

this stage may lack some, but not all, epitopes recognised by the PAb. After adsorbing the PAb to serial dilutions of an oyster cell homogenate, it was apparent the binding affinities of the resultant "purified" antibody to both parasite and host epitopes were no different to that of the unpurified antibody. This unintended reaction to oyster cell membranes may 
be specific whereby the combining site of the antibody recognizes determinants in both parasite and oyster antigens. Such redundancy (Benjamini and Leskowitz, 1991) may have arisen because the parasite antigen used to produce the antibody was contamined with host tissue. Another explanation may be, soluable antibody-antigen complexes were not removed from the antisera during the adsorption method and the antibody transferred to the sectioned material used in the immunohistochemical tests. It is also possible that the parasite has evolved methods to evade host immunity such as molecular mimicry or adsorption of host antigens (see Behnke, 1990). Monoclonal antibodies would resolve these problems because antibodies specific only to parasite epitopes could be selected and those recognising host tissue could be discarded. As none of the Marteilia sp. Monoclonal antibodies cross-reacted with $M$. sydneyi it appears there is a need to develop a MAb for QX disease diagnosis if an immunoassay is to be developed for commercial use.

The results of the QX IFAT show that the polyclonal antibody has a high specificity and that sporulating stages of Marteilia sydneyi are antigenically different to those of the closely related species, $M$. refringens, M. maurini, Marteilia sp. and Marteilioides branchialis. Roubal et al. (1989) found the same QX IFAT did not cross-react with myxosporidean parasites from fish commonly found at oyster leases during QX outbreaks. The results confirm that Marteilioides branchialis is a distinct species and not an aberrant
Marteilia sydneyi sporulation as considered (but rejected) by Anderson and Lester (1992). The high specificity of polyclonal antibody makes the QX IFAT a useful tool in finding at least the sporulating stages of Marteilia sydneyi in the environment.

Although the IFAT is a quicker method to use, the IGSS technique achieved a higher sensitivity when visualised by polarized light epi-illumination microscopy and can be easily adapted for use on resin embedded material at both the light (Barta and Corbin, 1990) and electron level (De May, 1984); this method would expedite the process of visualising the infective stage of $M$. sydneyi using IEM by initially allowing it to be localized at the light level. The failure to find presporulation stages in inflamed tissue suggests that the stages may have membrane antigens different to those of the sporulating stages that are recognised by the polyclonal antibody. Stage-specific antigens have been found to occur in another protoctistan parasitic of oysters, Haplosporidium costale. Polyclonal antibodies directed against the sporoplasm may overcome this problem (Burreson, 1988).

Preliminary attempts to follow the path of the spore using the QX IFAT on water samples collected from beneath trays of oysters infected with Marteilia sydneyi have failed due to the large volume of suspended matter in the water. A DNA probe for $M$. sydneyi is likely to overcome the problems associated with testing water samples and with stage-specific antigens.

\section{Acknowledgments}

This paper represents part of doctoral dissertation of the senior author whilst supported by an Australian Postgraduate Research Award. We thank Dr F. R. Roubal from the Department of Parasitology, University of Queensland, for making his polyclonal antibody available to the study.

\section{REFERENCES}

Anderson, T. J., R. J. G. Lester, 1992. Sporulation of Marteilioides branchialis n. sp. (Paramyxea) in the Sydney Rock Oyster, Saccostrea commercialis - an electron microscope study. J. Protozool., 39, 504-508.

Barta, J. R., J. Corbin, 1990. Use of immunogold-silver staining to visualize antibody-antigen complexes on LR White embedded tissues prior to electron microscopy. J. Electron Microsc. Techn., 16, 83-84.

Behnke, J. M., 1990. Parasites: Immunity and Pathology. Taylor \& Francis, London.

Benjamini E., S. Leskowitz, 1991. Immunology: A Short Course 2 nd ed. Wiley-Liss, Inc., New York.

Burreson E. M., 1988. Use of immunoassays in haplosporidian life cycle studies. Am. Fish. Soc. Spec. Publ., 18, 298-303.

Comps M., 1970. Observations sur les causes d'une mortalité anormale des huîtres plates dans le bassin de Marennes. Rev. Trav. Inst. Pêches marit., 34, 317-326.
Comps M., Y. Pichot, P. Papagianni, 1982. Recherches sur Marteilia maurini n. sp. parasite de la moule Mytilus galloprovincialis (Lmk.). Rev. Trav. Inst. Pêches marit., 45, 211-214.

De Mey J., 1984. Colloidal gold as marker and tracer in light and electron microscopy. EMSA Bull., 14, 54-66.

Grizel H., M. Comps, J. R. Bonami, F. Cousserans, J. I. Duthoit, M. A. Le Pennec, 1974. Recherches sur l'agent de la maladie de la glande digestive de Ostrea edulis (Linné), Science et Pêche, Bull. Inform. Inst. Pêches marit., 240, 7-30.

Humason G. L., 1979. Animal Tissue Techniques. 4th ed. W.H. Freeman \& Co., San Francisco.

Lester R. J. G., 1986. Field and laboratory observations on the oyster parasite Marteilia sydneyi. In: Parasite Lives. M. Cremin, C. Dobson, D. Moorhouse, eds., Univ. Queensland Press, Brisbane, Australia, 33-40.

Perkins F. O., P. H. Wolf, 1976. Fine structure of Marteilia sydneyi sp.n. -Haplosporidian pathogen of Australian oysters. J. Parasitol., 62, 528-538. 
Robledo J., E. Bachère, V. Boulo, E. Mialhe, B. Novoa, M. M. Santarem, J. Caceres, A. Figueras, 1994. Marteilia in Mytilus equalis (L.) and Mytilus galloprovincialis (Lmk.). Serological differences using monoclonal antibodies. In: Proc. 4th Int. Coll. on Pathology in Marine Aquaculture (in press).

Roubal F. R., J. Masel, R. J. G. Lester, 1939. Studies on Marteilia sydneyi, agent of QX disease in the Sydney Rock Oyster, Saccostrea commercialis, with implications for its life cycle, Aust. J. Mar. Freshw. Res., 40, 155167.

Springall D. R., G. W. Hacker, L. Grimelius, J. M. Polak, 1984. The potential of the immunogold-silver staining method for paraffin sections. Histochemistry, 81, 603$\epsilon 03$.

Witney E., J. Beumer, G. Smith, 1988. Oyster Culture in Queensland. Department of Primary Industries, Queensland Government, Brisbane. 